\title{
Reactive nitrogen and greenhouse gas flux interactions in terrestrial ecosystems
}

\author{
Per Ambus • Ute Skiba • Klaus Butterbach-Bahl • \\ Mark A. Sutton
}

Received: 16 March 2011 / Accepted: 18 March 2011 /Published online: 2 April 2011

(C) Springer Science+Business Media B.V. 2011

Nitrogen is an essential element for plant growth, which has fostered an extensive anthropogenic alteration of the natural nitrogen cycle by the application of fertilizers to optimize crop yields in agriculture and forestry. As a consequence the abundance of reactive nitrogen species has increased in soil, surface- and ground waters and in the atmosphere, leading to environmental problems in terms of global warming (IPCC 2007), eutrophication and changes in C and $\mathrm{N}$ flows in natural ecosystems due to progressive nitrogen inputs (e.g., Matson et al. 2002). The terrestrial cycling of nitrogen is intimately linked to biogeochemical processes in soil and plants, and the exchange

Responsible Editor: Hans Lambers.

P. Ambus $(\varangle)$

Biosystems Division, Risø National Laboratory for

Sustainable Energy, Technical University of Denmark,

Frederiksborgvej 399,

4000 Roskilde, Denmark

e-mail: peam@risoe.dtu.dk

U. Skiba $\cdot$ M. A. Sutton

Centre for Ecology and Hydrology,

Bush Estate, Penicuik,

Midlothian EH26 0QB Scotland, UK

K. Butterbach-Bahl

Institute for Meteorology and Climate Research,

Atmospheric Environmental Research,

Karlsruhe Institute of Technology,

Kreuzeckbahnstraße 19,

82467 Garmisch-Partenkirschen, Germany processes which cross the soil-plant-atmosphere boundaries. Knowledge about the causality between, on the one hand, anthropogenic perturbations and environmental conditions and, on the other hand, the exchange rates of reactive nitrogen species is still incomplete and need further attention.

This Special Issue presents research addressing this necessity derived from the European Integrated Project (IP) NitroEurope and presented at The 5th General Assembly and Open Science Conference in Solothurn, Switzerland, February 2010. The 11 publications compiled in this Special Issue focus on the mechanistic understanding of reactive nitrogen fluxes in relation to land management and environmental conditions at experimental scales from plot to landscape.

The turnover, transformation and flux of reactive nitrogen species is inevitably associated to the activity of soil microorganisms in the rhizosphere. Therefore, our ability to understand the ecosystem functioning in terms of nitrogen fluxes requires further insight into the microbiologically mediated processes. The first three publications comprise batch incubation studies addressing the relationship between soil nitrogen cycling, greenhouse gas fluxes and soil microbial community composition in relation to management and climatic conditions for a series of sites across Europe. Under future climate scenarios, increased frequency of fires in Mediterranean environments is expected (IPCC 2007). Dannenmann et al. (2011, this issue) elucidate the interaction between soil gross nitrogen turnover, greenhouse gas and di-nitrogen gas production in a 
Mediterranean shrub-land exposed to fire and find reduced microbial $\mathrm{N}$ retention and denitrification $\mathrm{N}$ gas losses. Inselsbacher et al. (2011, this issue) emphasize the influence of anthropogenic activity in terms of interactions between greenhouse gas emissions, soil microbial composition, plant growth and application of different nitrogen fertilizer types. They study two agricultural soils and provide evidence that ammonia oxidizing archaea play a significant role in nitrous oxide emissions pointing at the selection of mineral fertilizer type as an important mitigation option. Atmospheric nitrogen depositions has a critical impact on natural ecosystems (Matson et al. 2002), and in the third paper, Zechmeister-Boltenstern et al. (2011, this issue) demonstrate the impacts on soil microbial composition along an European forest gradient representing 12 sites with different vegetation covers and atmospheric nitrogen loads. The work indicates that natural vegetation controls on soil microbial community structures is masked by elevated nitrogen depositions.

Concentrations of reactive nitrogen in the atmosphere also influence forest canopy nitrogen dynamics that may exhibit a significant seasonality (e.g., Duyzer et al. 1994); this is investigated by Wang et al. (2011, this issue) examining a beech forest canopy in Denmark. They find that canopy net nitrogen emissions in early and late season, respectively can be related to leaf nitrogen mobilization during foliation and leaf nitrogen remobilization during senescence.

The significant importance of agricultural plant production for emissions of carbon and nitrogen species is well established (IPCC 2007), asking for knowledge to make progress in implementing mitigation measures, such as in the form of fertilizer use and the design of crop rotations. These issues are addressed in four papers in this Special Issue, where experimental work has been performed at the field plot scale. Mapanda et al. (2011, this issue) present data on greenhouse gas emissions and maize crop yields from Zimbabwe in southern Africa, a region sparsely represented in current literature. Specifically, they compare the effects of different types, mineral vs. compost, and amounts of fertilizer on nitrous oxide fluxes in different years, and suggest that composting manure might provide a probable management tool to reduce nitrous oxide emissions. Ranucci et al. (2011, this issue) revise current knowledge about nitrous oxide emissions in rotations with maize and grass-clover under Mediterranean climate conditions. Emission factors for different crop species were well below the $1 \%$ recommended by IPCC; amongst several physio-chemical parameters significant for the nitrous oxide emissions, the soil water regime was identified most important. A greater presence of leguminous plant species has the potential to increase soil nitrogen concentrations (e.g., Herridge et al. 2008) and thus potentially also surface emissions of nitrogen containing gases, a question taken up by Klumpp et al. (2011, this issue) studying the impact of clover density in intensively managed grass-clover pasture. The study included application of nitrogen15 labeled fertilizer in order to establish the contribution of different nitrogen pathways to the gaseous emissions, and shows that whereas soil and plant-nitrogen recoveries were independent of clover abundance a trend in data suggested an inverse relationship with nitrous oxide emissions. A far-reaching dataset for assessment of crop production sustainability is provided by Loubet et al. (2011, this issue). They studied a four-year rotation of maize- winter wheatwinter barley - mustard and provide data on impacts on gaseous and water mediated fluxes and overall budgets for carbon and nitrogen during crop growth and management. A key message of their study is that the crop rotation was a net source of greenhouse gases with a significant contribution from soil respiration, suggesting that management practices to reduce soil respiration provide a promising mitigation option.

Estimates of greenhouse gas emission from arable systems can be facilitated by application of process oriented models that incorporate the multiple drivers for soil nitrogen turnover. A growing number of models have emerged, but there is still a need to improve and verify existing ones. Chirinda et al. (2011, this issue) compare two models, FASSET and MoBILE-DNDC applied to three organic and one mineral fertilizer based crop rotations. The two models were specifically verified against field observations on nitrous oxide and carbon dioxide emissions, soil mineral nitrogen pools, soil temperature, soil water and plant biomass production. Both models exhibited limitations in their performance, in particular for the organic based crop rotations, confirming the need for further improvement.

Ernfors et al. (2011, this issue) studied the influence of mycorrhizal fungi-a distinct and abundant group of soil microorganisms existing in symbiosis with plant - on soil nitrogen cycling. To do so 
they conducted a trenching study in a Norway spruce stand to examine the effects of excluding sequentially tree roots and ectomyccorhizal fungi on soil emissions of nitrous oxide. By this it could be demonstrated that nitrous oxide emissions doubled when fungi and roots were excluded from the soil.

The last publication in this Special Issue concerns the non-stop development of soil-plant gas flux chambers with new designs and recommendations for their use. In this publication, Christiansen et al. (2011, this issue) compare vented vs. non-vented and mixed vs. non-mixed chambers deployed to a testing facility and provide recommendations for optimal chamber design and use. They show that deployment of vented chambers with continuous headspace mixing by fan is highly recommended.

Together these contributions show how significant advances are being made in our quantification and understanding of the nitrogen cycle. For this we are particularly grateful to the European Commission through its Sixth Framework Programme for Research and Technological Development, which has supported the NitroEurope IP, together with cofunding from many national bodies, as well as the European Science Foundation for its support of the Nitrogen in Europe (NinE) programme and the COST Action 729. This special issue provides a contribution to the work of the European Centre of the International Nitrogen Initiative, a joint project of the International Geosphere Biosphere Programme (IGBP) and the Scientific Committee on Problems of the Environment (SCOPE). We wish to thank all contributors who made this Special Issue possible.

\section{References}

Chirinda N, Kracher D, Lægdsmand M, Porter JR, Olesen JE, Petersen BM, Doltra J, Kiese R, Butterbach-Bahl K (2011) Simulating soil $\mathrm{N}_{2} \mathrm{O}$ emissions and heterotrophic $\mathrm{CO}_{2}$ respiration in arable systems using FASSET and MoBiLEDNDC. Plant Soil 343:139-160

Christiansen JR, Korhonen JFJ, Juszczak R, Giebels M, Pihlatie M (2011) Assessing the effects of chamber placement, manual sampling and headspace mixing on
$\mathrm{CH}_{4}$ fluxes in a laboratory experiment. Plant Soil 343:171-185

Dannenmann M, Willibald G, Sippel S, Butterbach-Bahl K (2011) Nitrogen dynamics at undisturbed and burned Mediterranean shrublands of Salento peninsula, Southern Italy. Plant Soil 343:5-15

Duyzer JH, Verhagen HLM, Weststrate JH, Bosveld FC, Vermetten AWM (1994) The dry deposition of ammonia onto a douglas-fir forest in the Netherlands. Atmos Environ 28:1241-1253

Ernfors M, Rütting T, Klemedtsson L (2011) Increased nitrous oxide emissions from a drained organic forest soil after exclusion of ectomycorrhizal mycelia. Plant Soil 343:161170

Herridge DF, Peoples MB, Boddey RM (2008) Global inputs of biological nitrogen fixation in agricultural systems. Plant Soil 311:1-18

Inselsbacher E, Wanek W, Ripka K, Hackl E, Sessitsch A, Strauss J, Zechmeister-Boltenstern S (2011) Greenhouse gas fluxes respond to different $\mathrm{N}$ fertilizer types due to altered plant-soil-microbe interactions. Plant Soil 343:17-35

IPCC (2007) Climate Change 2007: Synthesis Report. Contribution of Working Groups I, II and III to the Fourth Assessment Report of the Intergovernmental Panel on Climate Change [Core Writing Team, RK Pachauri and A Reisinger (eds)]. IPCC, Geneva, Switzerland, 104 pp.

Klumpp K, Bloor JMG, Ambus P, Soussana J-F (2011) Effects of clover density on $\mathrm{N}_{2} \mathrm{O}$ emissions and plant-soil $\mathrm{N}$ transfers in a fertilised upland pasture. Plant Soil 343:97-107

Loubet B, Laville P, Lehuger S, Larmanou E, Flechard C, Mascher N, Genermont S, Roche R, Ferrara RM, Stella P, Personne E, Durand B, Decuq C, Flura D, Masson S, Fanucci O, Rampon J-N, Siemens J, Kindler R, Gabrielle B, Schrumpf M, Cellier P (2011) Carbon, nitrogen and greenhouse gases budgets over a four years crop rotation in Northern France. Plant Soil 343:109-137

Mapanda F, Wuta M, Nyamangara J, Rees RM (2011) Effects of organic and mineral fertilizer nitrogen on greenhouse gas emissions and plant-captured carbon under maize cropping in Zimbabwe. Plant Soil 343:67-81

Matson P, Lohse KA, Hall SJ (2002) The globalization of nitrogen deposition: consequences for terrestrial ecosystems. Ambio 31:113-119

Ranucci S, Bertolini T, Vitale L, Di Tommasi P, Ottaiano L, Oliva M, Amato U, Fierro A, Magliulo V (2011) The influence of management and environmental variables on soil $\mathrm{N}_{2} \mathrm{O}$ emissions in a crop system in Southern Italy. Plant Soil 343:83-96

Wang L, Xu Y, Schjoerring JK (2011) Seasonal variation in ammonia compensation point and nitrogen pools in beech leaves (Fagus sylvatica). Plant Soil 343:51-66

Zechmeister-Boltenstern S, Michel K, Pfeffer M (2011) Soil Microbial Community Structure in European Forests in Relation to Forest Type and Atmospheric Nitrogen Deposition. Plant Soil 343:37-50 